\title{
Teaching Shared Value through university-business contaminations
}

\author{
By Simone Scagnelli ${ }^{1,2}$ and Laura Corazza ${ }^{2}$ \\ ${ }^{1}$ School of Business and Law, Edith Cowan University, Perth, Australia email s.scagnelli@ecu.edu.au \\ ${ }^{2}$ Department of Management, University of Turin, Turin, Italy email 1.corazza@ unito.it
}

\begin{abstract}
This paper presents and discusses the pedagogical implication of teaching Shared Value, presenting a case study about a contamination lab namely the case of the Shared Value Living Lab (SVLL) which took place during 2015-2018 at the University of Torino (UniTO) in Italy. The paper analyzes the pedagogical side of CSV (arguments, topics, learning methodologies, etc.) in the framework of recent theories and approaches of teaching sustainability in business school and in the cooperation between industry and academia, as well. Our research methodology relies on the analysis and comparison of one case study under an intrinsic as it enables researchers to find "interactivity" and connectedness between the individuals participating. The SVLL case is an interesting example of co-creation of social value between academia and its stakeholders. First, it represents an inclusive project linking society and business; second, SVLL acted as a hub putting in contact different interlocutors; third, SVLL training stimulated the acquisition of soft skill in students (interviews, managing relations, represents the project outside university, explaining the project to people, research curiosity) through contamination activities. With our study, we demonstrate the change in students participating in the SVLL may not only be cognitive but also affective, making students feel hopeful, empowered and liberated, and ready to contribute to a more profound change towards the vast array of pro-sustainability behaviors.
\end{abstract}

Keyword Creating Shared Value; university-business contamination; living lab; sustainability science

JEL: A20-M4-M21-O35-I23

\section{Introduction}

Over the last two decades, an increasing number of corporations and businesses have become aware of their ethical, social and environmental issues and, in general, of the link between corporate responsibilities and corporate sustainability. Theories and approaches over CSR and its non-financial accounting emerged shaping the relationships between business and society [1,2]. Recently, the brand-new concept of Shared Value Creation (CSV) came up disturbing the debate on corporate strategies and CSR, stakeholder management theory, social innovation, and philanthropy as well [3]. Even CSV has instigated the debate between academic supporters and detractors of this new approach, practitioners, consultants, professionals, managers and students has been attracted by the opportunity to create economic value and social wellbeing, at the same time. Of course, the use of the Porter's name as a "brand" has brought great audience, but conversely it has positively put in contact the needs of different organisations, among which, MNCs, SMEs, social enterprises, public administrations, accountants and professionals, to discuss together their mutual roles [4]. In addition, the vision of a business's value creation process that can be influenced by mechanism of commonality, cooperation and coopetition implies the need of updating universities' curricula about such new insights. In the meanwhile, universities and business schools are experiencing new forms of collaboration and partnering sharing common interest versus the concept and the achievement of sustainable development of people and countries. Several partnering modes arose in this last few years, and other will be tested in the near future as the imperative of a sustainable value creation is becoming a common ground. The main aim of this study is to present and argue about a user-centred, open-innovation ecosystem, and blended learning platform, based on the concept of Shared Value; namely the case of the Shared Value Living Lab (SVLL) which took place during 2015-2016 at the University of Torino (UniTO) in Italy. The ability to collaborate effectively in order to increase the possibility of generating blended value is not innate [5,6]. An article by Ruff and Olsen (2016) points out that the ability to compare, evaluate, measure and taking account and control of social impact creation, is a matter 
of understanding the differences between "apples and oranges". Accordingly, SVLL is a research project aimed at provide good insights and skills to students aimed to create future managers with "open" mindsets. The project is aimed at: create concrete academic training through "learning by doing methods", enriching the skills and mindsets for students (interviewing local actors); collaborate to develop the local entrepreneurial context involving companies (mostly SMEs) through mechanism of shared value (in situ visits); create new scientific knowledge around CSV; jointly collaborate with other local actors to foster a new managerial culture towards sustainability. Given that UniTo is a 600 years-old generalist university, practical and innovative blended research-learning approaches are not usual. The paper will analyze the pedagogical side of CSV (arguments, topics, learning methodologies, etc.) in the framework of recent theories and approaches of teaching sustainability in business school and in the cooperation between industry and academia, as well. After the presentation of the case, a profound discussion of the pros and cons of such blended and interactive researchlearning ecosystem will be presented. Consequently, we compare the main features derived from an applied research project to other similar projects that took place and/or several other learning mechanisms put in place in other universities. Given, such aims, our methodological approach adopts an intrinsic case study perspective [7]. Because CSV overlaps several existent concepts, this will affect its accountability and reporting practices. Therefore, our findings demonstrate the current shift from traditional corporate social and sustainability reporting mainstream to the hegemonic role of non-financial reporting and accountability, in profit, public and mission-driven organization, as well as hybrid ones [8,9]. Our study enriches and bring valuable insights to existent literature and practice in sustainability, CSR and social innovation, because it presents practical and real issues in shaping innovative contamination activities, as well as the soft skills useful to shape not only future managers, but importantly, future conscious citizens.

\section{Pedagogical issues of teaching sustainability}

University research organizations and higher education institutions (HEIs) play an relevant role contributing to the technologies, strategies, citizens, and leaders require for a more sustainable future [6]. The process of synchronization of social acceptance of the HEI efforts towards sustainable development, by social actors, starts from the inner recognition of such universities social responsibilities and their communication [10]. In that sense, it is even more common that universities are recognizing their social responsibilities in teaching activities, research practices and, as in their third-mission, as social innovators [11]. In their role of social actors, HEIs collaborate to co-jointly formulating policies, developing and marketing products and test innovative processes with industries, universities and public, and a multitude of stakeholders at a local or global level [12,13]. In the framework herein depicted, universities generally, may adhere to global universities association to develop graduates for a changing business context to achieve global environmental sustainability and social justice such UN Global Compact, the Global Reporting Initiative, Principles for Responsible Management Education and the Globally Responsible Leadership Initiative [14]. In addition, they may adhere to responsible research and innovation programmes [15] and they may put in place third mission actions towards sustainable development, such for instance, university-industry projects, public engagement activities, knowledge transfer, co-creation [16].

In order to create significant learning for students, it is necessary a strong commitment at the institutional level (faculty, university), also through mechanism of stewardship or norm-making approach, that permits the operating application at the curricular level (course design, modules) using specific methodologies at the instrumental level. Sterling [17] proposes three potential levels of response by HEIs in teaching sustainability. The first is an accommodative response (educating about sustainability), the second approach is a reformative response of educating for sustainability, while the third is a transformative response of capacity building where students adopt skills needed for sustainability. Another issue related to sustainability education is those of interdisciplinary vs multidisciplinary approach. For instance, according to Pappas (2012), universities need to develop values-based sustainability content for classes across disciplines, and especially address the careful assessment and evaluation of both human and technical factors for solving sustainability problems. His work clarifies that sustainability issues focus on integrated multidisciplinary perspectives than treatment of environmental resources and the inevitable waste resulting from the production of goods and services. In fact, according to the nascent concept of sustainability science, Pappas (2012) notes five different contexts (social/cultural, economic, environmental, technical, and individual). Jerneck et al. [18] argue that 
sustainability science must face sustainability issues in interdisciplinary rather than disciplinary ways, bridging the divide between natural and social sciences. The study focuses more on the research fields, highlighting how sustainability issue may impact problem solving phase and critical research, and it does not consider the teaching side. Similarly, the matrix of Painter-Morland et al. (2016) holistically assumes that the research activities are covered, but it does not discuss the role of pedagogical effect of learning by doing methodologies in sustainability sciences. Conversely, a study performed by Kagawa (2007) shows that students associate the concepts uni-dimensionally with the environment rather than embracing a holistic (multi-dimensional) interpretation that is required by the topic itself [19]. In fact, there is a nascent problem of how education for sustainable development translates research outcomes of sustainability science into educational practices and guides the selection of learning objectives, relevant content and appropriate forms of teaching and learning [20]. For instance, the case of UNAM university is Mexico and its efforts in creating a collaborative environment to set up a sustainability science programme, specifies that among the existent traditional pedagogical approaches, to real world project-based, problem-based learning tools, student-driven research projects, interactive lectures and group dynamics are the most suitable teaching techniques [21-24]. This is because sustainability education needs to merge research and teaching activities into a transformative learning outcomes of students and stakeholders, to demonstrated its effectiveness [25].

As argued by Setó-Pamies \& Papaoikonomou (2016), more innovative approaches, such as management games and simulations contribute to a supporting environment for students and complement other methodologies. Realistic classroom experiences might be more effective, because otherwise it might become a sort of indoctrination as autocratic repetition of official definitions and limiting standards [26].

Hughes and Troy [27] studied the development of an interdisciplinary course designed to teach upper-level undergraduate students how to develop an Environmental Management System (EMS) for a small business enterprise through a simulation in which student interdisciplinary teams act as employees of a consulting firm. In addition, gamification can play a pivotal role in teaching sustainability. A research project tested the effectiveness of pervasive game for sustainability learning as part of a class [28]. As young kids play games having fun and learning comes naturally, teach sustainability sciences through system thinking gives the students a real-world experience with the development of a game.

Games and virtual environments serve as an informal learning environment for children of all ages. Gamification is also about formalizing these informal "learning environments", and using them beneficially in traditional learning and class environments. Also, the active, participative learning central to a drama is particularly useful for allowing students to develop skills in communication, collaboration and expressing ideas and opinions. As experimented by McNaughton [29] the immersion in the imagined context and narrative, integral to the 'stories' in the drama, allows them to feel sympathy for and empathy with people who are affected by environmental issues and problems.

Another pedagogical method is those of Problem- and Project- Based Learning (PPBL) where students, researchers and practitioners work together closely in order to find an appropriate answer to a sustainability question and they create benefits for all participants [30]. In the model of Brundiers \& Wiek (2013), authors stressed several core features of the problem vs. project approach: engage students in real-world tasks; studentcentered small-group work; stimulate professional situation; processing multiple information sources; teacher as facilitator for learning and resource guide; formative and performance-based (peer) evaluations. With the aim of merging together action learining and sustainability, Jiusto et al. [31] published a dissertation over several examples of Shared Action Learning (SAL) where students involved in such programs engage directly with challenges associated with promoting sustainability and fostering institutional and social change within a specific community context. In this case studies, often researchers assisted to a shift from technological solutions, or problem solving, to the importance of relationships, networks and communication for all the stakeholders involved. As a matter of fact, Mauser et al. [32] debated the concept of trandisciplinarity (union of academic and non-academic partners) and interdisciplinarity (solely academics) and they conclude that the concept of co-creation is based on the integration of co-design, co-production and jointly diffusion of knowledge. More deeply, the paper argues that in order to obtain an optimal integration, three dimensions should be considered: the scientific integration between natural, social and engineering disciplines; the international integration from local to global and across nations and cultures; finally, the sectoral integration across science and society. Another pedagogical approach is those of Solution-oriented sustainability learning 
(SOSL) experiences [33]. SOSL is competencies-based and experiential, which allows students 'learning while transforming.' Similarly to participatory action learning, problem-based learning, project-based learning, and other active learning approaches, SOSL inverts the traditional direction of teaching from (instructor delivers and students receive), to active (students deliver while instructor receives and provides feedback) [34,35].

Another pedagogical tool to adress sustainability issues is those of a Living Lab [36,37]. In addition, with the attempt of going beyond the physical and political boundaries of an HEIs there is the paramount importance of the institutional role played by knowledge-intensive institution [38]. The institutionalization of the commitment towards sustainability science permits to set up a network of collaboration not only focused on project or problem, but broadly on sharing common efforts with HEIs' stakeholders. Among the broad concept of stakeholders there are industries. And, the university-industry collaborations are at the core of the sustainability science [39]. The work of Orecchini et al. (2012) explores the footprint of sustainability science in terms of traditional scientific disciplines and it demonstrates that social sciences, biology, chemical, mechanical, civil engineer are those more related to publications linked to research, in the timeline 1992-2008.

\section{Teaching sustainability in business school}

About teaching sustainability at business school, Starik et al. (2010) note the need of more transformative sustainability results in management education. The question of teaching sustainability in business schools has been modeled by Rusinko/Godemann et al. [40,41], where Painter-Morland et al. [23] added a new dimension concerned to systemic institutional integration. The matrix discussed by Painter-Morland et al. (2016) analyses the integration of environmental, social, governance and organizational ethic issues in the curricula of a sample of European business schools. Several degrees of "sustainability orientation" are stressed, defining a horizontal and vertical extent, from few hours of lessons in an existent course, to a broad institutional commitment, existing and new core, cross-disciplinary curricula [42]. The model herein presented is suitable for business schools, but teaching, researching and creating an outreach impacts, in a generalist HEI could imply several issues of coordination between disciplines [43]. In fact, the broad research of Lozano et al. [44] discusses the integrative framework that characterize the orientation of the HEIs towards the sustainable development evidencing several interrelated elements [45].

Among the formation and creation of a broad multi-disciplinary sustainability science, management and accounting disciplines and its scholars and professors as well, can contribute to a more sustainable/less unsustainable society throughout a process of reinvigoration of accounting and sustainable development investigations [46]. A paucity of study deals directly with the role of management and accounting disciplines for sustainability education, using innovative pedagogical way merging teaching and research practices. The case of sustainable entrepreneurship and the newer form of social and environmental entrepreneurship have been debated by scholars stressing the link between managerial skills and ecological orientation; while, social entrepreneurship and inclusive business represent a di per se distinct filed of analysis [47,48]. Business ethics education, social responsibility education and social accounting education are included in the model of PainterMorland et al. [23]. even though there is a scarcity of studies that narrate the integration of such topics in business curricula [49]. Additionally also the use of information can have a strong impact on the adoption or not of a specific learning or teaching methodology[50-54]. re is little information on what these methods are and which of them is best to teach CSR and if these methods comprise research and third mission activities [55]. Globally, an attempt of rationalization of approaches is given by NBS movement (Network for Business Sustainability) that map 56 sustainability centers, hosted in HEIs, mainly located in the American continent. This is even more complex if applied at the notion of CSV, as multiple contradictory topics and critics are related to it since its publication [3,56-59]. In fact, CSV is related to CSR, social innovation, inclusive business, stakeholder engagement, despite is "innovativeness" [60,61].

\section{Methodology}

Our research methodology relies on the analysis and comparison of one case study under an intrinsic perspective [62]. Case study research normally encompasses three categories: (i) intrinsic, (ii) instrumental, 
and (iii) collective (or multiple). The former is often exploratory in nature, and the researcher is guided by the interest in the case itself rather than in extending theory or generalizing across cases. On the other hand, an instrumental case study is secondary to the exploration of a specific issue, because the purpose is to go beyond the case by building theory or redrawing generalizations. A collective or multiple case study arises when the purpose of the case study is mixed and combined, for instance, an instrumental study is extended to several cases. They are chosen because their analysis should lead to better understanding, and perhaps better theorizing than a focus on a single case [63].

Because, our main and enduring interest is to focus Shared Value Living Lab project, its uniqueness, and how it can contribute to further understanding, it represents an intrinsic case study approach. Moreover, the adoption of this case study approach enables researchers to find "interactivity" and connectedness between the individuals participating while transferring the experiences of the participants to the reader through the development of a story or stories that describe the case. Indeed, the SVLL has been participatory in its evolution, as the project followed a co-creation multi-stakeholder approach involving MNCs, SMEs, social enterprises, public administrations, public organizations (such chamber of commerce) and universities, as well. Therefore, narrative discussion of the results is provided to enrich and bring valuable insights to the existent literature and practice on Shared Value creation.

\section{The Shared Value Living Lab case}

The Shared Value Living Lab (SVLL) is a project developed by the Department of Management of the University of Torino, Italy between April 2015 and December 2016. A living lab is by an user-centered open innovation environment, developed in a real-life settings in which new services (i.e. knowledge, education, etc.), products, and societal infrastructures are usually co-created with the users/participants, thus encompassing societal and technological dimensions simultaneously in a business-citizens-governmentacademia partnership [64]. Consistently with this definition, the purpose of the SVLL has been to: (i) provide solid training and education in sustainability-related topics through learning by doing methods, and by enriching the skills and mindsets of the students; (ii) collaborate in enhancing the local entrepreneurial context involving companies (mostly SMEs) throughout mechanisms of shared value creation; (iii) suggest a model of economic, social, responsible and solid system based on the adoption of Creation of Shared Value (CSV) business models; (iv) create new scientific knowledge around CSV; (v) collaborate with other local actors to foster a new managerial culture on sustainability and CSR. Because, the SVLL has been developed by researchers belonging to the School of Management and Economics of the University of Torino, the majority of the involved students had such a background. The following paragraphs provide specific insights, and critically discuss, the activities of the SVLL [65].

\section{Co-creation and multi-stakeholder engagement.}

The SVLL activities has been divided in several phases and tasks. The first phase was exclusively theoretical, where researchers performed a literature review previously presented (middle 2015) and deriving insights useful to set up the core initiatives. The second phase has been practical and consisted of public engagement initiatives dedicated to students to present them the multifaceted concepts of CSV and select suitable candidates interested in exploring the knowledge of CSV in a concrete manner. These activities consisted of seminars and roundtable. Third, after having selected a group of candidates the Living Lab activities started and consisted of traditional training activities and outdoor explorations such as action learning. Fourth, the Living Lab selected few cases to be used to test and engage students in experiencing concretely what they have learnt.

Following the well-known concepts of triple helix, SVLL has been designed to engage in n-tuple helices where each helix corresponds to one group of stakeholder. As a matter of fact the project has been engaging with several stakeholders each one with different features, and goals: local agencies (Social Entrepreneurship Committee of the Turin Chamber of Commerce, and its Innovative Enterprise sector), Higher Education Organisations (Laurea University of Applied Science, Espoo, Finland), inclusive businesses developers (DeLab srl), entrepreneurial associations (local Union of Small Enterprises, and local Union of Young Entrepreneurs); associations of students (AIESEC). In the first phases of the engagement with stakeholders, 
the process has been almost uni-directional, meaning that researchers have presented them the roadmap proposing and asking for legitimization of the lab activities and projects. For instance, Table 1 provides a list of the public engaging activities aimed at selecting and involving the participants in the SVLL.

Table 1 Seminar and public engagement activities herein the experience of SVLL

\begin{tabular}{|l|l|l|l|l|}
\hline $\begin{array}{l}\text { Public engagement } \\
\text { activity }\end{array}$ & Participants & $\begin{array}{l}\text { Nr. of students } \\
\text { involved }\end{array}$ & Curriculum & Theoretical linkages \\
\hline $\begin{array}{l}\text { Multinational } \\
\text { corporation in } \\
\text { approaching CSV }\end{array}$ & $\begin{array}{l}\text { FCA (Fiat Chrysler } \\
\text { Automobilies) }\end{array}$ & 350 & 1 st year Bachelor & $\begin{array}{l}\text { Strategic CSR, } \\
\text { innovation in supply } \\
\text { chain, social impact } \\
\text { assessment of social } \\
\text { related projects }\end{array}$ \\
\hline $\begin{array}{l}\text { Social entrepreneurship } \\
\text { and inclusive business }\end{array}$ & $\begin{array}{l}\text { Rete del dono (crowd } \\
\text { philanthropy), } \\
\text { Impact Hub (sharing } \\
\text { economy), } \\
\text { Torino Social } \\
\text { Innovation (local } \\
\text { government project) }\end{array}$ & 200 & $\begin{array}{l}\text { 2nclusive business, } \\
\text { philanthropy, social } \\
\text { innovation }\end{array}$ \\
\hline $\begin{array}{l}\text { Creation of shared } \\
\text { value within the local } \\
\text { context }\end{array}$ & $\begin{array}{l}\text { Chamber of } \\
\text { Commerce, Industrial } \\
\text { Union and local hub of } \\
\text { Reseau Entreprendre }\end{array}$ & 100 & 3 rd year Bachelor & $\begin{array}{l}\text { Entrepreneurship and } \\
\text { consciousness }\end{array}$ \\
\hline
\end{tabular}

Such public engagement initiatives allowed to collect more than one hundred students' CVs, however, given the features of the SVLL only 15 students have been selected as lab's users/participants after a motivational colloquium. These students have been engaged in several training sessions (in class lectures, and multimedia MOOC's based), and on the-field explorations related to the following topics:

- Stakeholder management theory (in cooperation with a local social enterprise adopted as case study);

- Sustainability reporting and international guidelines (i.e. GRI, IIRC, UN GC);

- New tools for sustainability assessment in SMEs (www.csr4utool.org);

- Social impact assessment databases (TRASI, Standards Map);

- Inclusive business models (cooperation with DeLab);

- Sustainability issues in learning and education (jointly with Metropolia University of Applied Science - Helsinki lecturer, and students' exchange);

- Living Labs, Smart Cities and Inclusive Society (visiting Open Incet, council centers for Open Innovation privately funded);

- Social innovation and Social Impact Investment (visiting Magazzini Oz, a local social cooperative founded with the purpose of social solidarity, in their renewed building a shop-library-restaurant in the city center)

- Public engagement activities at the University's Research Night and Terra Madre fair (SlowFood) in collaboration with UNESCO Chair on Sustainable Development.

Finally, to provide a practical field of activity, the fourth phase of the project involved carrying out some business-academia projects with selected organizations. Several companies, almost SMEs, have been engaged to co-jointly develop CSV related projects by a team of students.

\section{Discussion}

\section{The pedagogical side of CSV}

So far, CSV-related terminology tends to be simplistic, and quite superficial while it argues about linking business and societal goals [66]. As such, the pedagogical design of SVLL embraced the CSV umbrella concept as criticized by the literature but indeed useful to demonstrate our students the slight differences between CSR, philanthropy, social impact measurement, and social and sustainability reporting. The choice of adopting a grounded and practical perspective, carrying the students inside the organizations have given them the ability to distinguish the different models argued by the literature and the melting pot of the CSV-related 
concepts. All the students state that they have learned more during the SVLL activities than in hours of traditional university lectures. Most of them requested to have a direct part in scientific studies around the SVLL and to conduct on their own several interviews to local partner to know more and more about sustainability rooted organizations.

\section{Issues and difficulties in SVLL management}

Of course, researchers faced some difficulties in running and managing the living lab. These can be especially related to the engagement of the stakeholders due to limited time and resources to dedicate at the project, business partners' external pressures, difficulties to really understand the meaning of strategic CSR, and absolute ignorance on CSV which is often misunderstood. Only one project out of three ended with a concrete outcome within the planned timeline. The project was about the development of a sustainability report of a SME in the textile industry. Another, ended just after few months because the involved organisation (a familyfirm) decided to continue their sustainability path following the "directives" received by their customers (MNCs of electronic equipment) such as paying for having a social audit. Other three projects are still ongoing (two of them are on stakeholder salience models for two distinct associations, the third is related to developing a new product for an inclusive business). One fourth SME is interested in developing projects together and it came once project has already started.

On other hand, even engaging with the participants has been sometimes difficult. Students have been enthusiastic in the on-the-filed activities and training, but often missed some of the in-class training activities. However, this is normal given the pilot features of the first classes, that have commonly an intrinsic risk. Moreover, we took contact with several other similar initiatives world-wide, to exchange good practices and insights. Finally, more than a real Living Lab, we experienced a contamination lab.

\section{Conclusions}

The SVLL case is an interesting example of co-creation of social value between academia and its stakeholders. First, it represents an inclusive project linking society and business; second, SVLL acted as a hub putting in contact different interlocutors; third, SVLL training stimulated the acquisition of soft skill in students (interviews, managing relations, represents the project outside university, explaining the project to people, research curiosity) through action research activities. Concluding, from the experience gained during SVLL activities, organizations, companies, local agencies, perceived CSV as a renovate propulsion towards a sustainable business conducts, without putting much emphasis on the concepts itself. Concluding, we can affirm that more researches are needed to disentangling the process of CSV and concretely demonstrate how it overlap existent concepts, and how it diverges from them. The creation of knowledge on sustainability is closely related to research activities which are developed within the business schools [67]. We believe that the change in students participating in the SVLL may not only be cognitive but also affective, making students feel hopeful, empowered and liberated, and ready to contribute to a more profound change towards the vast array of pro-sustainability behaviors. This framework aims to facilitate the development of ability to think in new ways and to engage with different worldviews. This is important and has been proved in the context of the MBA students that, according to Stubbs and Cocklin [68], usually given their exposure to mainstream economics and business administration courses. The goal is therefore to move critical thought by engaging on responsible business and sustainability from different perspectives, rather than presenting a single version of sustainability to them. Our results are in line with Birtch and Chiang [69], demonstrating that integrative approaches to teach sustainability, ethics, societal, and environmental responsibilities are effective more than traditional. A limit of our study is to be focused on one sole case study, and in order to generalize the results herein discussed other cases could enhance the replicability and its strength and weaknesses, as well.

\section{Bibliography}

1. Garriga, E.; Melé, D. Corporate social responsibility theories: Mapping the territory. J. Bus. Ethics 2004, 53, 51-71. 
2. Gray, R.; Owen, D.; Adams, C. Some theories for social accounting?: A review essay and a tentative pedagogic categorisation of theorisations around social accounting. In Sustainability, Environmental Performance and Disclosures; Advances in Environmental Accounting \& Management; Emerald Group Publishing Limited, 2009; Vol. 4, pp. 1-54.

3. Porter, M.E.; Kramer, M.R. The Big Idea : Creating Shared Value. Harv. Bus. Rev. 2011, 89, 1-2.

4. Scagnelli, S.D.; Cisi, M.; Corazza, L. Behaviors on Sustainability Accounting. How SMEs play the game. 2013.

5. Emerson, J. The blended value proposition: integrating social and financial results. Calif. Manage. Rev. 2003, 45, 35-51.

6. Nicholls, A. "We do good things, don't we?": "Blended Value Accounting" in social entrepreneurship. Accounting, Organ. Soc. 2009, 34, 755-769.

7. Stake, R. The Art of Case Study Research. Thousand Oaks, CA Sage 1995, 49-68.

8. Armano, B.; Scagnelli, S.D. Governance and Financial Performances: Evidence from NTBFS (NewTechnology Based Firms) Governed by Academic People. Manag. Entrep. Dev. Mediterr. Area 2009, 150.

9. Hellmann, A.; Scagnelli, S.D. Behavioral accounting: Shifting away from techniques to people. 2011.

10. Moggi, S.; Leardini, C.; Campedelli, B. Social and Environmental Reporting in the Italian Higher Education System: Evidence from Two Best Practices. In Integrative Approaches to Sustainable Development at University Level; Springer International Publishing, 2015; pp. 81-96 ISBN 3319106899.

11. Goddard, J.; Kempton, L.; Vallance, P. The civic university. Connecting the global and the local. In Universities, Cities and Regions: Loci for Knowledge and Innovation Creation; 2013; pp. 43-61 ISBN 9780203097144.

12. Leydesdorff, L.; Etzkowitz, H. Emergence of a triple helix of university-industry-government relations. Sci. Public Policy 1996, 23, 279-286.

13. Leydesdorff, L. The Triple Helix, Quadruple Helix, ..., and an N-Tuple of Helices: Explanatory Models for Analyzing the Knowledge-Based Economy? J. Knowl. Econ. 2012, 3, 25-35.

14. Adams, C.; Petrella, L. Collaboration, connections and change. Sustain. Accounting, Manag. Policy J. 2010, 1, 292-296.

15. Owen, R.; Macnaghten, P.; Stilgoe, J. Responsible research and innovation: From science in society to science for society, with society. Sci. Public Policy 2012, 39, 751-760.

16. Trencher, G.; Yarime, M.; McCormick, K.B.; Doll, C.N.H.; Kraines, S.B. Beyond the third mission: Exploring the emerging university function of co-creation for sustainability. Sci. Public Policy 2014, 41, 151-179.

17. Sterling, S. Higher Education, Sustainability, and the Role of Systemic Learning. In Higher Education and the Challenge of Sustainability: Problematics, Promise, and Practice; Corcoran, P.B. Wals, A.E.J., Eds.; Springer Netherlands: Dordrecht, 2004; pp. 49-70 ISBN 978-0-306-48515-2.

18. Jerneck, A.; Olsson, L.; Ness, B.; Anderberg, S.; Baier, M.; Clark, E.; Hickler, T.; Hornborg, A.; Kronsell, A.; L??vbrand, E.; et al. Structuring sustainability science. Sustain. Sci. 2011, 6, 69-82.

19. Kagawa, F. Dissonance in students' perceptions of sustainable development and sustainability. Int. J. Sustain. High. Educ. 2007, 8, 317-338.

20. Barth, M. Teaching and Learning in Sustainability Science. In Sustainability Science: An Introduction; Heinrichs, H., Martens, P., Michelsen, G., Wiek, A., Eds.; Springer Netherlands: Dordrecht, 2016; pp. 325-333 ISBN 978-94-017-7242-6. 
21. Charli-Joseph, L.; Escalante, A.E.; Eakin, H.; Solares, M.J.; Mazari-Hiriart, M.; Gómez-Priego, P.; Domínguez Peréz-Tejada, C.A.; Bojórquez-Tapia, L.A.; Nation, M.; Gómez-Priego, P.; et al. Collaborative framework for designing a sustainability science programme: Lessons learned at the National Autonomous University of Mexico. Int. J. Sustain. High. Educ. 2016, 17, 378-403.

22. Brundiers, K.; Wiek, A.; Redman, C.L. Real-world learning opportunities in sustainability: from classroom into the real world. Int. J. Sustain. High. Educ. 2010, 11, 308-324.

23. Trencher, G.; Terada, T.; Yarime, M. Student participation in the co-creation of knowledge and social experiments for advancing sustainability: Experiences from the University of Tokyo. Curr. Opin. Environ. Sustain. 2015, 16, 56-63.

24. Luederitz, C.; Meyer, M.; Abson, D.J.; Gralla, F.; Lang, D.J.; Rau, A.L.; von Wehrden, H. Systematic student-driven literature reviews in sustainability science - an effective way to merge research and teaching. J. Clean. Prod. 2016, 119, 229-235.

25. Brundiers, K.; Wiek, A. Educating Students in Real-world Sustainability Research: Vision and Implementation. Innov. High. Educ. 2011, 36, 107-124.

26. Kopnina, H. Revisiting education for sustainable development (ESD): Examining anthropocentric bias through the transition of environmental education to ESD. Sustain. Dev. 2014, 22, 73-83.

27. Hughes, R.C.; Troy, M.A. Teaching Sustainability to Undergraduates: Evolution of a Course Structure and Development of a Model for Partnering with Local Small Businesses. Sustain. (United States) 2016, 9, 200-204.

28. Nordby, A.; Øygardslia, K.; Sverdrup, U.; Sverdrup, H. The art of gamification; teaching sustainability and system thinking by pervasive game development. Electron. J. e-Learning 2016, 14, $152-168$.

29. Marie Jeanne McNaughton *a Educational drama in the teaching of education for sustainability. Environ. Educ. Res. 2004, 10, 139-155.

30. Brundiers, K.; Wiek, A. Do we teach what we preach? An international comparison of problem- and project-based learning courses in sustainability. Sustain. 2013, 5, 1725-1746.

31. Jiusto, S.; Mccauley, S.; Stephens, J.C. Integrating Shared Action Learning into Higher Education for Sustainability. 2013, 5 .

32. Mauser, W.; Klepper, G.; Rice, M.; Schmalzbauer, B.S.; Hackmann, H.; Leemans, R.; Moore, H. Transdisciplinary global change research: The co-creation of knowledge for sustainability. Curr. Opin. Environ. Sustain. 2013, 5, 420-431.

33. Wiek, A.; Kay, B. Learning while transforming: solution-oriented learning for urban sustainability in Phoenix , Arizona. Curr. Opin. Environ. Sustain. 2015, 16, $29-36$.

34. Scagnelli, S.D. Business reporting for decision making: an integrated framework for information technology and information systems evaluation. Int. J. Sci. Environ. Technol. 2013, 2, 328-350.

35. Armano, B.; Scagnelli, S.D. Does the Governance by Academics influence Firms' Financial Performances? Evidence from New-Technology Based Firms (NTBFs). In Proceedings of the 33rd Institute for Small Business \& Entrepreneurship Conference; ISBE Institute for Small Business \& Entrepreneurship, 2010; pp. 1-11.

36. Nystrom, A.G.; Leminen, S. Living lab. A new form of business network. Concurr. Enterprising (ICE), 2011 17th Int. Conf. 2011, 1-10.

37. Leminen, S.; Westerlund, M.; Nyström, A. Living Labs as open-innovation networks. Technol. Innov. Manag. Re 2012, 6-11.

38. Yarime, M.; Trencher, G.; Mino, T.; Scholz, R.W.; Olsson, L.; Ness, B.; Frantzeskaki, N.; Rotmans, J. Establishing sustainability science in higher education institutions: Towards an integration of 
academic development, institutionalization, and stakeholder collaborations. Sustain. Sci. 2012, 7, $101-113$.

39. Orecchini, F.; Valitutti, V.; Vitali, G. Industry and academia for a transition towards sustainability: Advancing sustainability science through university-business collaborations. Sustain. Sci. 2012, 7 , $57-73$.

40. Rusinko, C. a Integrating Sustainability in Management and Business Education : A Matrix Approach. Manag. Learn. 2010, 9, 507-519.

41. Godemann, J., Herzig, C., \& Moon, J. Approaches to changing the curriculum. Presentation given on the ISIBS Workshop-Session II. In Proceedings of the SIBS Workshop-Session II; University of Nottingham: Nottingham, 2011.

42. Armano, B.; Scagnelli, S.D. Does the Presence of Academic People in Companies' Boards Influence Economic Performances? Evidence From Companies Grown in University Incubators (UIs). In Proceedings of the Proceedings of the 4th European Conference on Entrepreneurship and Innovation: ECIE; Academic Conferences Limited, 2009; Vol. 3, p. 11.

43. SCAGNELLI, S.; VASILE, L.; APOSTOLOV, M. SURVIVAL DRIVERS OF POST-INCUBATED START-UPS: THE EFFECT OF ACADEMIC GOVERNANCE. Int. J. Innov. Manag. 2018.

44. Lozano, R.; Ceulemans, K.; Alonso-Almeida, M.; Huisingh, D.; Lozano, F.J.; Waas, T.; Lambrechts, W.; Lukman, R.; Hugé, J. A review of commitment and implementation of sustainable development in higher education: Results from a worldwide survey. J. Clean. Prod. 2015, 108, 1-18.

45. Scagnelli, S.D. Corporate governance e disclosure nell'era dei social network, evidenze empiriche dall'area Euro.; Aracne, 2012.

46. Bebbington, J.; Larrinaga, C. Accounting and sustainable development: An exploration. Accounting, Organ. Soc. 2014, 39, 395-413.

47. Schaper, M. Making ecopreneurs : developing sustainable entrepreneurship; 2005; ISBN 075464491X (alk. paper).

48. Gibbs, D. Sustainable Entrepreneurs, Ecopreneurs and the Development of a Sustainable Economy. Greener Manag. Int. 2006, 55, 63-78 (16).

49. Sharma, U.; Kelly, M. Students' perceptions of education for sustainable development in the accounting and business curriculum at a business school in New Zealand. Meditari Account. Res. 2014, 22, 130-148.

50. Scagnelli, S.D. Il Product Lifecycle Management. In Management Information Systems; Cantino, V., Ed.; McGraw-Hill: Milano, 2005.

51. Scagnelli, S.D.; Armano, B. ACADEMIC GOVERNANCE AND CORPORATE FINANCIAL PERFORMANCE: EVIDENCE FROM POST-INCUBATED NEW TECHNOLOGY BASED FIRMS (NTBFs).

52. Scagnelli, S.D. Information Communication Technology (ICT) e azienda: Analisi, valutazione e orientamento agli stakeholders; Giappichelli: Torino, 2017;

53. Scagnelli, S.D. The Open Access Model, Trends and Opportunities in Accounting Research. Open J. Account. 2014, 3, 1-2.

54. Ciartano, C.; Scagnelli, S.D.; Hellmann, A. The Effect of adopting cost or fair value measurements on financial statements: the case of IAS40-investment property. 2012.

55. Turker, D.; Vural, C.A.; Samuel, O.I. Social Responsibility Education Across Europe: A Comparative Approach; Turker, D., Vural, C.A., Idowu, S.O., Eds.; Springer International Publishing, 2016;

56. Moon, H.-C.; Pare, J.; Yim, S.H.; Park, N. An Extension of Porter and Kramer's Creating Shared Value (CSV): Reorienting Strategies and Seeking International Cooperation. J. Int. Area Stud. 2011, 
$18,49-64$.

57. Crane, A.; Palazzo, G.; Spence, L.; Matten, D. Contesting the Value of "Creating Shared Value." Calif. Manage. Rev. 2014, 56, 130-153.

58. Beschorner, T. Creating Shared Value: The One-Trick Pony Approach. Bus. Ethics J. Rev. 2013, 1, 106-112.

59. Wilburn, K.; Wilburn, R. Demonstrating a Commitment to Corporate Social Responsibility Not Simply Shared Value. Bus. Prof. Ethics J. 2014, 33, 1-15.

60. Truant, E.; Corazza, L.; Scagnelli, S.D. Sustainability and risk disclosure: An exploratory study on sustainability reports. Sustain. 2017, 9.

61. Corazza, L.; Scagnelli, S.D.; Mio, C. Simulacra and Sustainability Disclosure: Analysis of the Interpretative Models of Creating Shared Value. Corp. Soc. Responsib. Environ. Manag. 2017, 24, 414-434.

62. Stake, R.E. The art of case study research. art case study Res. 1995, 236-245.

63. Corazza, L.; Scagnelli, S.D. Legitimacy Reverbs of Mandatory Regulations on Sustainability Disclosure at a Worldwide Level. In Proceedings of the 8th Annual Conference of the EuroMed Academy of Business; EuroMed Press, 2015; pp. 2328-2330.

64. Kareborn, B.B.; Stahlbrost, A. Living Lab: an open and citizen-centric approach for innovation. Int. J. Innov. Reg. Dev. 2009, 1, 356.

65. Corazza, L.; Cisi, M.; Scagnelli, S.D. Creation of Shared Value in Action: The Case of a Living Lab Using Transformative Learning. J. Bus. Ethics Educ. 2018, 15.

66. Scagnelli, S.D.; Cisi, M. Approaches to shared value creation: CSR 2.0 or something more? Insights and issues about the new sustainability perspective. 2014.

67. Jabbour, C.J.C. Greening of business schools: a systemic view. Int. J. Sustain. High. Educ. 2010, 11, 49-60.

68. Stubbs, W.; Cocklin, C. Teaching sustainability to business students: shifting mindsets. Int. J. Sustain. High. Educ. 2008, 9, 206-221.

69. Birtch, T.A.; Chiang, F.F.T. The Influence of Business School's Ethical Climate on Students' Unethical Behavior. J. Bus. Ethics 2014, 123, 283-294. 